\title{
REVISION OF ANNESIJOA, ELATERIOSPERMUM AND THE INTRODUCED SPECIES OF HEVEA IN MALESIA (EUPHORBIACEAE)
}

\author{
HOANG VAN SAM ${ }^{1} \&$ PETER C. VAN WELZEN ${ }^{2}$
}

\begin{abstract}
SUMMARY
Annesijoa is an endemic monotypic genus from New Guinea with as single species A.novoguineensis. Elateriospermum is also monotypic (E.tapos) and found in West Malesia. The South American genus Hevea comprises about 10 species. One species (H.brasiliensis) is presently cultivated worldwide in plantations for its rubber and has become one of the major economic products of SE Asia. Two other species, $H$. guianensis and $H$. pauciflora are sometimes present in Malesian botanical gardens.
\end{abstract}

Key words: Euphorbiaceae, Annesijoa, Elateriospermum, Hevea, Malesia.

\section{INTRODUCTION}

Three genera are revised for Flora Malesiana, Annesijoa Pax \& K. Hoffm., Elateriospermum Blume, and Hevea Aubl. These genera are not very closely related, but they are all part of the subfamily Crotonoideae (Webster, 1994; Radcliffe-Smith, 2001), though classified in different tribes (Jatropheae, Elateriospermeae, and Micrandreae subtribe Heveinae, respectively). Typical for the Micrandreae are colporate pollen with a reticulate sexine, articulate laticifers, absent petals, and plenty of endosperm (oily in the Heveinae). The Jatropheae and Elateriospermeae share inaperculate pollen with a typical 'crotonoid' sexine, inarticulate laticifers, petals absent or not, and seeds with or without endosperm. They differ in several characters, the Elateriospermeae lack endosperm and have no petals, while these are present in the Jatropheae.

The three genera can easily be distinguished from each other. Hevea and Elateriospermum have white latex, whereas Annesijoa has variable latex ranging from clear to white to red. Hevea and Elateriospermum have glands at the transition from petiole apex to blade base, these are absent in Annesijoa. Elateriospermum has simple leaves, whereas the other two genera have compound leaves, trifoliolate in Hevea and 3-5(-7)-digitate in Annesijoa. Annesijoa and Hevea (and Bischofia) are the only Euphorbiaceae genera with compound leaves in Malesia. Other genera sometimes have deeply dissected leaves like some species of Manihot Mill. and Jatropha L. (genera relatively closely related to Annesijoa and Hevea). In the tribe Jatropheae there are also two other genera with compound leaves, the South American Joannesia Vell. and the

1) Forest Plant Department, Viet Nam Forestry University, Xuan Mai, Ha Tay, Viet Nam; e-mail: hsamfuv@yahoo.com

2) Nationaal Herbarium Nederland, Leiden Universiteit branch, P.O. Box 9514, 2300 RA Leiden, The Netherlands; e-mail: welzen@nhn.leidenuniv.nl 
West African Leeuwenbergia Letouzey \& N. Hallé (both with 2 spp.). The stamens of the three genera treated are also quite different. Annesijoa has 15-25 united stamens in three layers, Hevea has 4-10 united stamens in one or two layers, and Elateriospermum has 10-20(-22) free stamens in a single bundle.

Annesijoa and Elateriospermum are monotypic, indigenous genera in Malesia. Annesijoa is endemic in New Guinea and Elateriospermum is found in West Malesia. Hevea is originally found in South America, but it was introduced very successfully in Malesia. Several other species are only present in botanical gardens. Hevea brasiliensis is the major source of natural rubber in the world (out competing Manihot carthaginensis (Jacq.) Müll.Arg. subsp. glaziovii (Müll.Arg.) Allem. The production in SE Asia is excellent and due to the many cars and the HIV infection the demand for natural rubber is high, therefore it is planted in many plantations all over SE Asia. Nowadays, the wood (very light-coloured with beautiful patterns) is increasingly popular, providing new challenges to the rubber plantations.

\title{
TAXONOMIC TREATMENT
}

\begin{abstract}
ANNESIJOA
Pax \& Hoffmann (1919) described the monotypic genus Annesijoa. The name is an anagram of Joannesia. Annesijoa is easily recognised, because it is one of the very few genera in the Euphorbiaceae with a compound, digitate leaf, with variable latex. Its flowers with white petals make it an attractive plant. However, the horticultural value is probably low, because it is a large tropical tree.

Webster (1994) and Radcliffe-Smith (2001) classify Annesijoa in the subfamily Crotonoideae, tribe Jatropheae. Within the tribe Annesijoa shares a compound leaf with the South American Joannesia and the West African Leeuwenbergia (both with two species). However, the latter two have 2-locular ovaries, drupaceous fruits (or fruits unknown, respectively), and much broader stigmas (Annesijoa has a 3-localur ovary, dehiscent fruits, and slender, bisected stigmas).
\end{abstract}

\section{Annesijoa Pax \& K. Hoffm.}

Annesijoa Pax \& K. Hoffm. (1919) 9; (1931) 101; Airy Shaw (1960) 363, in key; (1963a) 345; (1967) t. 3632, p. 3, in observations; (1974) t. 3713; (1980) 27; G.L. Webster (1994) 104; Radcl.-Sm. (2001) 293. - Type: Annesijoa novoguineensis Pax \& K. Hoffm.

Tree, monoecious. Latex variable, clear to white or red. Indumentum absent except for a few simple hairs in the domatia, and on the petals and ovary. Stipules not seen, also no scars, either absent or small and early caducous. Leaves alternate, digitate, 3-5(-7)-foliolate, young leaves red; petiole long, basally and apically pulvinate; petiolules basally slightly thickened; leaflets symmetric, base attenuately narrowing into the petiolule, margin subentire, slightly crenate because of widely spaced glands (serrulate when young); upper and lower surface smooth, lower surface with slightly hairy pocket domatia in the nerve axils; venation pinnate, flat above, raised underneath. Inflorescences axillary to pseudoterminal panicles with staminate or mixed flowers, usually in consecutive axils forming a kind of terminal compound panicle, several 
staminate flowers per side branch, one per node; pistillate flowers single, terminal on main branches; bracts minute. Flowers unisexual, actinomorphic; calyx 5-lobed, cupular, slightly imbricate; petals 5, free, imbricate, spathulate, white; disc glands 5 or 6. Staminate flowers: stamens 15-25, united in 3 layers; the outermost splitting off first, the inner ones up to twice as long, free part of filaments short, anthers small, subglobose, 2-locular, basifixed, opening latrorsely with lengthwise slits; pistillode absent. Pistillate flowers: pedicel more robust than that of staminate flower; calyx not persistent; disc glands very small, enlarging in fruit; ovary ovoid, densely sericeous (to sometimes glabrous), 3-locular; one ovule per locule; style absent to very short, stigmas 3, oblique, flat, strap-like, apically deeply bilobed. Fruit a subglobose capsule, pedicel elongating, glabrescent, completely dehiscing loculicidally, only partly so septicidally (basal part excepted), dark brown to black when ripe, with a rather thick, woody endocarp. Seeds usually 3 developing per fruit, ovoid but flattened ventrally, ridged ventrally and dorsally, ecarunculate.

Distribution - Monotypic, as the species.

\section{Annesijoa novoguineensis Pax \& K. Hoffm. - Fig. 1; Map 1}

Annesijoa novoguineensis Pax \& K. Hoffm. (1919) 9; Airy Shaw (1960) 363, in key; (1963a) 345; (1967) t. 3632, p. 3, in observation; (1974) t. 3713; (1980) 27. - Type: Ledermann 10873 (n.v., probably $\dagger$ ), Papua New Guinea, Kaiserin Augusta Fluß-Expedition, (Hauptlager) Malu.

Tree, 15-40 m high, bole 10-33 m long, dbh 20-60 cm; buttresses absent to present, up to c. $1.3 \mathrm{~m}$ high and c. $50 \mathrm{~cm}$ wide. Outer bark c. $0.2 \mathrm{~mm}$ thick, smooth (to covered with many slightly raised lenticels), dark grey to grey-brown to brown; middle bark red to mottled red and cream to straw; inner bark 10-16 mm thick, straw to yellowish brown to red-brown, with some latex; sapwood c. $2 \mathrm{~cm}$ thick, white to brown; heartwood pink, moderately hard and heavy. Leaves: petiole 4-10(-20.5) cm long, round; petiolules absent to up to $2.5 \mathrm{~cm}$ long; leaflets elliptic to obovate, $5.5-23$ by $2-6 \mathrm{~cm}$, length/width ratio 2.7-3.5, chartaceous, base attenuate or acute, apex acuminate or rounded, upper surface green, drying greyish brown, lower surface light green, drying chestnut-brown; nerves 6-17 per side, looped and closed near the margin, veins widely reticulate to slightly scalariform. Inflorescences up to $18 \mathrm{~cm}$ long; branches up to $7.5 \mathrm{~cm}$ long; bracts triangular, c. 0.5 by $0.25 \mathrm{~mm}$. Flowers with a pleasant fragrance; peduncle $0.5-5.5 \mathrm{~cm}$ long; petals obovate, margin entire, apex rounded. Staminate flowers 1.5-3.2 mm diam.; pedicel 5-12 mm long, calyx 2-3.2 mm deep, lobes ovate, $1-1.5$ by $1-1.4 \mathrm{~mm}$, veins inconspicuous; petals $5-8(-14)$ by $2-4 \mathrm{~mm}$, hairy outside only, veins 5 or 6 ; disc glands obovate or elliptic, $1-1.2$ by $0.3-0.8 \mathrm{~mm}$; filaments $0.4-1.2(-3) \mathrm{mm}$ long, thread-like; anthers $0.7-0.9$ by $0.8-0.9 \mathrm{~mm}$. Pistillate flower: pedicel $0.8-1.6$ ( -2 in fruit) $\mathrm{cm}$ long, calyx $2-2.5 \mathrm{~mm}$ high, lobes ovate, $0.8-1.2$ by 1-1.6 mm, veins inconspicuous; petals $8-13$ by $4-5 \mathrm{~mm}$, veins inconspicuous; disc glands obovate or elliptic, $0.4-1$ by $0.3-0.7 \mathrm{~mm}$; ovary $3-3.5$ by $2.2-2.6 \mathrm{~mm}$; stigmas $1-1.2 \mathrm{~mm}$ long. Fruits $2.5-3.5$ by $2.1-2.6 \mathrm{~cm}$, wall $2-2.7 \mathrm{~mm}$ thick, smooth. Seeds 10-12 by $7-11 \mathrm{~mm}$, dark brown.

Distribution - Endemic in New Guinea.

Habitat \& Ecology - Locally common in the canopy layer of dense primary, mixed forest with little undergrowth, disturbed forest, lower mountain Castanopsis-Oak rain 


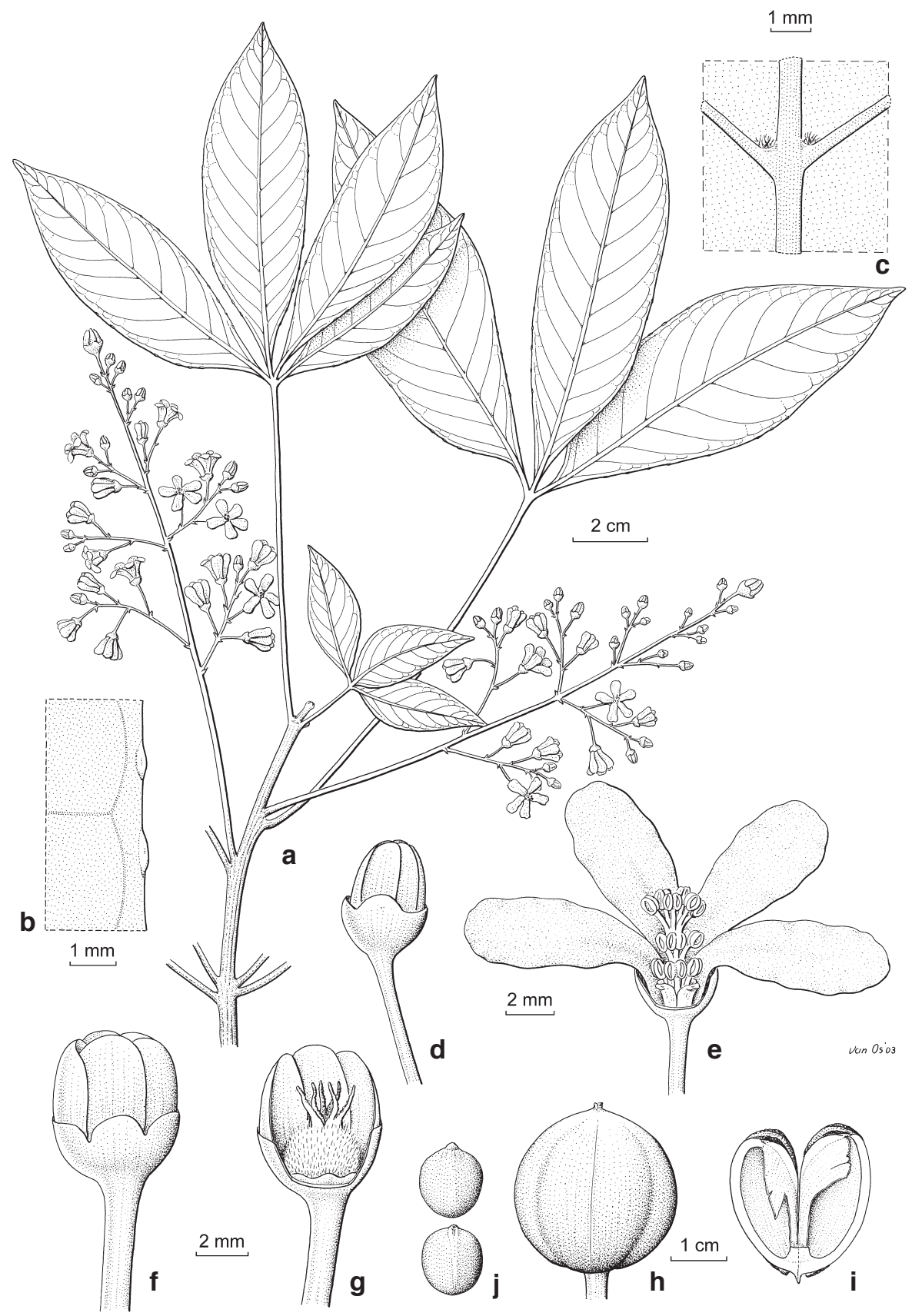

Fig. 1. Annesijoa novoguineensis Pax \& K. Hoffm. a. Habit; b. leaf margin underneath with glands; c. hair tuft domatia; d. bud; e. staminate flower; f. pistillate flower; g. pistillate flower with part of calyx and petals removed; $h$. fruit; i. fruit valves, completely dehisced loculicidally, partly septicidally; j. seeds in ventral and dorsal view (a-g: Brass 32407; h: LAE (Streimann) 51712; i, j: Pullen 7319; all L). 


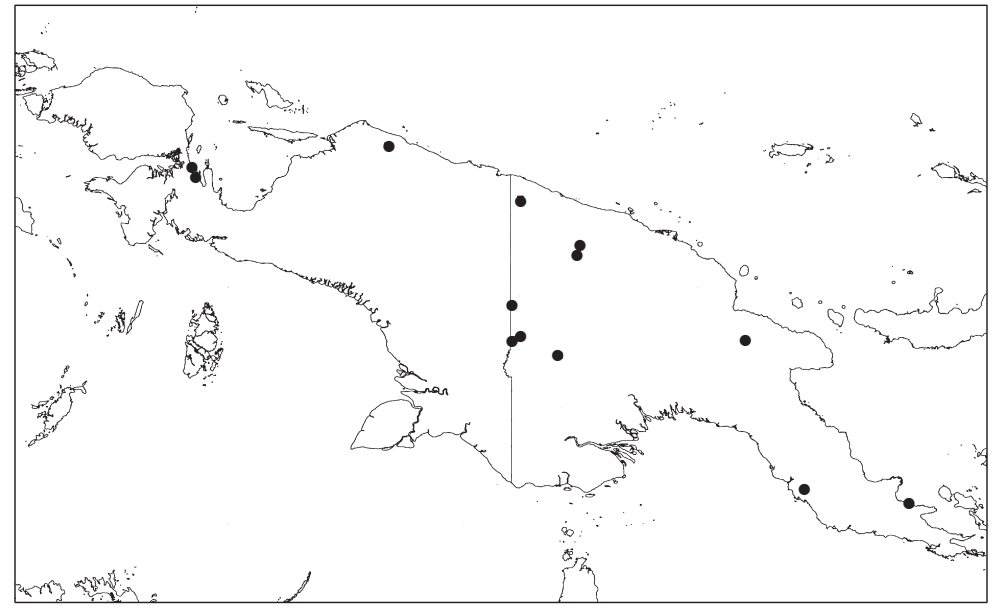

Map 1. Distribution of Annesijoa novoguineensis Pax \& K. Hoffm.

forest. Altitude: $60-1370 \mathrm{~m}$. Flowering twice per year: March to May, October to November; fruiting twice per year: January to February, June to August.

Vernacular names - Kovi-imi (Waskuk); Masjiw, sasor (Wandammen); Teweja / tweja (Kwerba); Umoo (Kilifas).

Note - The literature is not clear about the presence of latex in Annesijoa, while the specimens examined are variable and mention the latex to be slightly sticky to sticky, clear to white to red (LAE 51712, NGF 31831, Pullen 7319).

\section{ELATERIOSPERMUM}

Blume (1825) described the monotypic genus Elateriospermum. Elatérios is Greek for to chase away, sperma refers to seed: plant of which the seeds are launched by the fruit during dehiscence (a character rather typical for most Euphorbiaceae). Typical characters are the presence of white latex; obovate, long-petioled, simple leaves with two glands at the base of the blade; staminate flowers with 4 or 5 imbricate sepals, no petals and 10-20(-22) stamens; pistillate flowers with 4-6(-7) sepals (the variation is somewhat larger than described by Radcliffe-Smith, 2001). Elateriospermum is classified by Webster (1994) and Radcliffe-Smith (2001) in the subfamily Crotonoideae and the monogeneric tribe Elateriospermeae. Typical characters are: Monoecy, white latex, slender obovate leaves on a long petiole with adaxial, apical glands, absent petals, disc, pistillate flowers with staminodes, large fruits, inaperturate, crotonoid pollen.

\section{Elateriospermum Blume}

Elateriospermum Blume (1825) 620; Müll.Arg. (1866) 1130; Benth. (1879) pl. 1294; Hook.f. (1887) 381; Boerl. (1900) 226; J.J. Sm. (1910) 571; Pax (1910) 17; Ridl. (1924) 252; Corner (1940) 249; Backer \& Bakh.f. (1964) 496; Airy Shaw (1963b) 371; Meijer (1967) 25; Airy Shaw (1972) 258; Whitmore (1973) 91, f. 6; Airy Shaw (1975) 108; (1981) 292; G.L. Webster (1994) 102; Radcl.Sm. (2001) 286. - Lectotype (Webster, 1994): Elateriospermum tapos Blume. 
Tree, monoecious. Latex white (to yellowish), sticky, usually abundant, in non-articulated laticifers. Indumentum mainly absent, simple hairs in young parts and inflorescences. Stipules small, early caducous. Leaves simple, alternate, crowded at end of the twigs; petiole relatively long, basally slightly pulvinate, apically pulvinate with 2 disc-like glands adaxially; blade coriaceous, bright red when young, margin entire; venation penninerved, veins and veinlets reticulate. Inflorescences bisexual, axillary to terminal, long-peduncled, cymose panicles, with dichasial terminal branches, central flower of each cyme usually pistillate, rarely staminate. Flowers: pistillate ones larger than staminate ones; sepals in 2 whorls, strongly imbricate, free; petals absent; disc present, densely pilose, with stamens or staminodes inserted in excavations. Staminate flowers: sepals 4 or 5, puberulous; disc thick, fleshy, lobulate, with long white hairs; stamens 10-20(-22), free, filaments short, anthers narrowly obovate, 2-celled, basifixed, opening introrsely with a longitudinal slit, connective apiculate with a gland, thecae parallel; pistillode minute, hairy, or absent. Pistillate flowers: sepals 4-6(-7); staminodes numerous, minute, subulate, ovary ovoid, 2-4-locular, villose; ovules single per locule; style very short; stigmas bend horizontally, apical part split, both parts vertical, one descending, broad and scale-like, the other ascending, triangular. Fruit a large capsule, splitting septicidally and usually partly loculicidally, leaving bivalved cocci; wall rather thick, exocarp somewhat fleshy, endocarp woody. Seeds large, usually 3 per fruit, obovoid with a thin crustaceous chestnut brown testa, ridged ventrally and dorsally, ecarunculate; endosperm scarce; embryo large, white.

Distribution - Monotypic, as the species.

\section{Elateriospermum tapos Blume - Fig. 2; Map 2}

Elateriospermum tapos Blume (1825) 621; Müll.Arg. (1866) 1131; Benth. (1879) pl. 1294; Hook.f. (1887) 382; Boerl. (1900) 227; J.J. Sm. (1910) 572; Pax (1910) 17; Merr. (1921) 344; Ridl. (1924) 252; K. Heyne (1927) 942; Burkill (1935) 905; Corner (1940) 249; Backer \& Bakh.f. (1964) 497; Airy Shaw (1963b) 371; Meijer (1964) 17; (1967) 25; Medway (1972) 131; Airy Shaw (1972) 258; Whitmore (1973) 91,f. 6; Airy Shaw (1975) 108; (1981) 293; Smitinand (2001) 215. - Lectotype (selected here): Blume 2127 (L), Indonesia, Java, Bantam.

Tree, up to $27(-50) \mathrm{m}$ high, dbh up to $56 \mathrm{~cm}$, bole up to $10 \mathrm{~m}$ high, sometimes shortly fluted or with buttresses up to $2 \mathrm{~m}$ high, $1.2 \mathrm{~m}$ wide and $15 \mathrm{~cm}$ thick; crown deeply conical, hemispherical, multilayered, monopodial. Outer bark dirty white to (grey-) brown, c. $1 \mathrm{~mm}$ thick, hard, smooth to finely fissured and slightly scaly with c. $1.5 \mathrm{~cm}$ long flakes; inner bark red to pale brownish to partly pale yellowish, c. $10 \mathrm{~mm}$ thick, fibrous, firm; sapwood white to light yellow; heartwood dark brown. Stipules triangular, 2-3 mm long. Leaves: petiole 1-8 cm long, flat or somewhat hollow adaxially; blade elliptic to obovate, $5-24$ by $2-7.5 \mathrm{~cm}$, length/width ratio $2.5-3.2$, base obtuse to cuneate, apex abruptly acuminate to cuspidate, upper and lower surface smooth, dark green above, paler beneath; venation raised especially below, nerves 7-17 per side, looped and closed near the margin. Inflorescences up to $19 \mathrm{~cm}$ long, hairy, cymules $0.5-6 \mathrm{~cm}$ long, bracts triangular, $1-1.4$ by $0.7-1 \mathrm{~mm}$, peduncle $2-9 \mathrm{~cm}$ long. Flowers white to pale yellow, fragrant with unpleasant scent; buds white. Staminate flowers 2.4-3.5 mm diam.; pedicel 2-7 mm long, hairy; sepals ovate, $2.5-6$ by $2.2-5 \mathrm{~mm}$, apex rounded, puberulous outside, glabrescent; disc $0.8-1.3 \mathrm{~mm}$ high; stamens yellow, filaments $0.3-2 \mathrm{~mm}$ long, orange at base, anthers $0.8-1.2$ by $0.2-0.4 \mathrm{~mm}$. Pistillate 

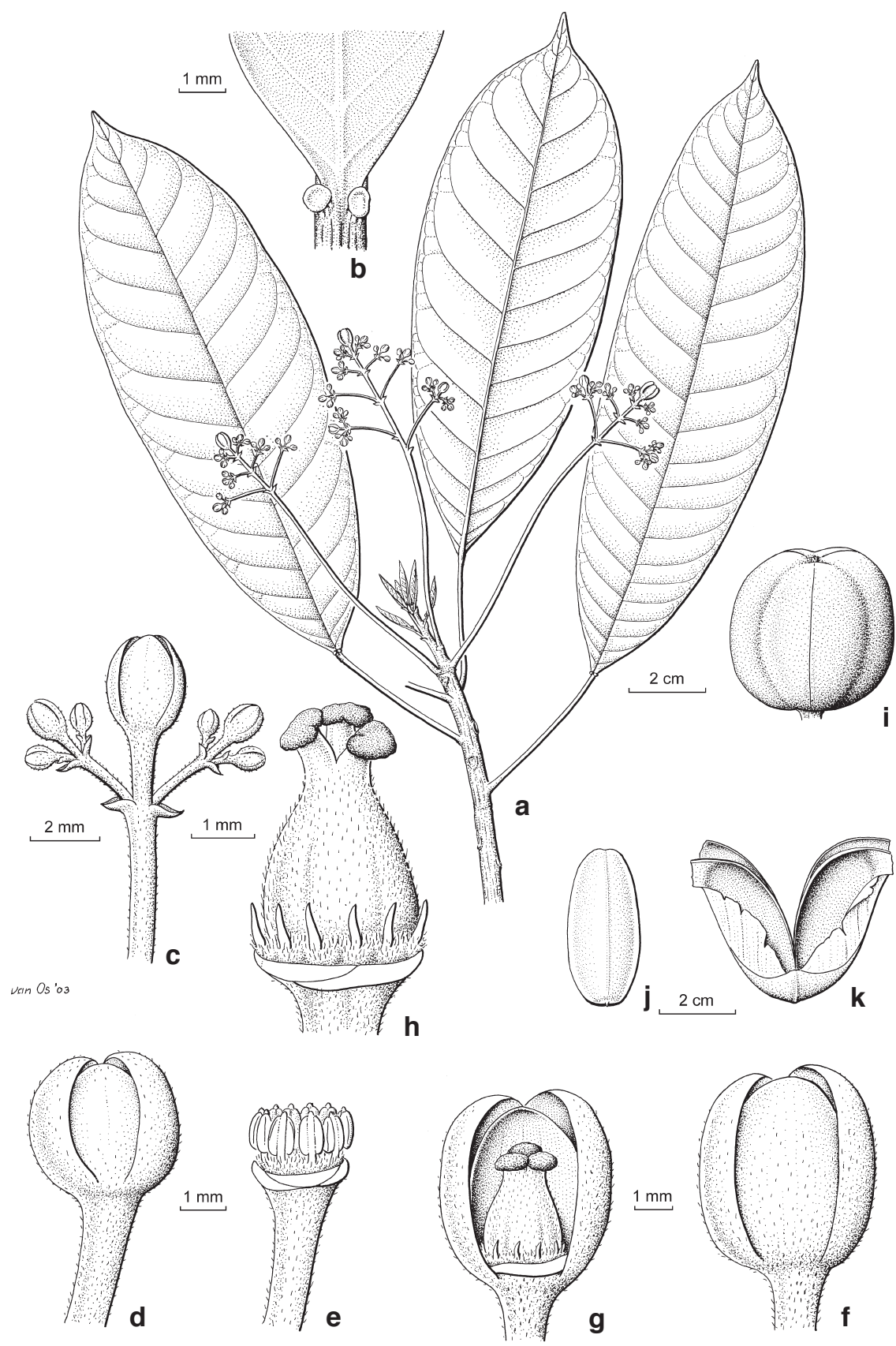

Fig. 2. Elateriospermum tapos Blume. a. Habit; b. basal leaf glands; c. dichasial part of inflorescence, large flower pistillate, rest staminate; d. staminate bud; e. staminate flower with sepals removed; f. pistillate bud; g. pistillate flower with part of sepals removed; h. pistil with disc lobes; i. fruit; j. seed; $k$. fruit valves with complete septicidal dehiscence and partly loculicidal dehiscence (a-h: KL (Teo \& Pachiappan) 3309; i-k: Burley, Tukirin et al. 1600; all L). 


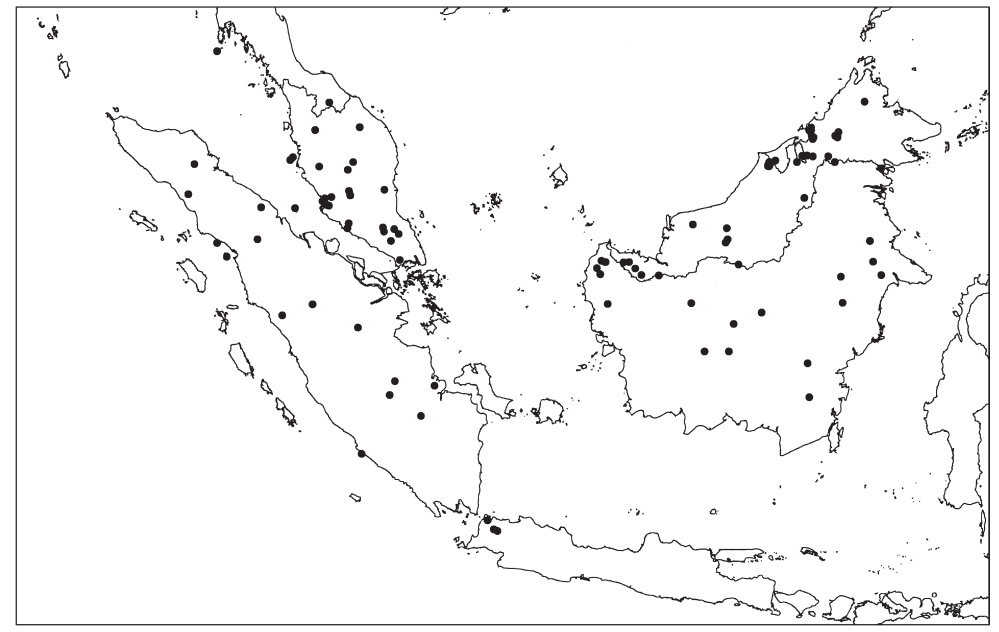

Map 2. Distribution of Elateriospermum tapos Blume.

flowers 3.2-5.3 mm diam.; pedicel 1.3-4.2(-50 in fruit) $\mathrm{mm}$ long, hairy; sepals ovate, $4.5-8$ by $3.2-5.5 \mathrm{~mm}$; disc $1-1.3 \mathrm{~mm}$ high; ovary ovoid, $2.5-4$ by $2-2.6 \mathrm{~mm}$, densely hairy, light green; style and stigma thick, $0.3-0.5 \mathrm{~mm}$ long. Fruits oblong-ellipsoid, longitudinally 3 -grooved, $3.2-5.3$ by $2.2-4.5 \mathrm{~cm}$, glabrous, exocarp changing from green via red to turning dark brown (to black), endocarp yellowish. Seeds 3.2-3.6 by $1.4-2.2 \mathrm{~cm}$, brown-grey to dark brown, smooth.

Distribution - S Peninsular Thailand, Malay Peninsula, Sumatra, Java, Borneo.

Habitat \& Ecology - In hilly primary (mixed dipterocarp) and secondary forest, kerangas forest, forest edges, along logging roads; soil usually deep and yellow-coloured, mainly clay, clay-loam, sandy clay, loam, sometimes sandstone or (silty) laterite. Altitude: sea level up to $600 \mathrm{~m}$. Flowering and fruiting throughout the year. The flowers are visited by dammar bees.

Vernacular names - Thailand: Kra, pra (Thai); pi-ra (Bidayuh-Malay) (Smitinand, 2001). Malay Peninsula: (Buah) perah, perah kokong (Burkill, 1935; Whitmore, 1973); gua pra, ple prah (Sakai); piah, suing (Semang). Sumatra: Asiloem (Karo); daun tepoes, kajoe si marsang-sang, kedoei, tapoes. Java: Tap(p)os (Sundanese) (Blume, 1825). Borneo: Bramban; kelampai (Iban-Sarawak); layang layang; paha; perah, perah ikan (Malay); rampeh, rapi (Bidayuh)

Uses - A tree of ornamental value. Its flowering indicates the start of the rice season. The seeds are mainly used, but they are usually poisonous (cyanide) when fresh (though a few races are without cyanide). The seeds can be eaten cooked or roasted, but too much may cause dizziness. On Sumatra a paste is made of the seeds (pounded with some water) and used to flavour some kinds of sambal; jungle tribes (Sakai) in Malaysia bury the paste packed in a bag or in bamboo in wet earth for a month or more, the result is a fermented paste with a strong flavour, which is highly appreciated with meals. The fermented paste is also used as fish bait. The oil is seldom pressed from the seeds, pale yellow, nearly odourless and with a nice taste, to be used for cooking or as lamp oil. The wood is usually considered as excellent. The sapwood is white, the 
heartwood with beautiful dark brown flames. However, it is mainly used as firewood or for small items like handles of rubber tapping knives, because it takes a nice polish. It could have been a good construction timber, but only the sapwood is durable, the heartwood rots easily or is attacked by termites unless treated with preservatives. The seeds make nice toys for children, they are used as toy beetles or threaded together in a game called 'conquerors'. The latex is used on Sumatra to shield dirty wounds, because it dries quickly; the Bidayuh in Sarawak apply fresh latex once per day to crack wounds on the soles of their bare feet. The latex is also used to polish blowpipes to a glossy dark sheen (Malay Peninsula). Partly after Heyne (1927) and Burkill (1935).

\section{HEVEA}

Aublet (1775) described Hevea. He used the name erroneously, because it refers to the Ecuadorian Indian name 'hevé', which is Castilla elastica Cerv. (Moraceae). However, the description and plate of Aublet is of such quality that the correct identification of his plant is without doubt. Schultes (1970a, b) described the history of Hevea, but this part is rather brief and the references are missing. According to him, four years later Richard proposed a new name for Hevea: Siphonia. However, the only reference to Siphonia and Richard is in Von Schreber's edition of Linnaeus' Genera Plantarum of 1791, where there is indeed also a reference to Aublet's name Hevea. This makes Siphonia in fact a superfluous name, because Hevea is nomenclatorally correct, even though the vernacular name refers to another plant. Gmelin (1791) introduces the name Caoutchoua elastica for Aublet's Hevea guianensis, referring to a name in Linnaeus (1781), Jatropha elastica. This is again a superfluous name as Aublet is also referred. Finally, Robert Brown (Bennett \& Brown, 1844) introduced the fourth genus name, Micrandra (M. ternata), a name now rejected in favour of Bentham's Micrandra (erroneously a genus thought to be closely related to Hevea).

Hevea comprises about 10 species, all from South America. However, H. brasiliensis has become one of the most economically important species worldwide and is cultivated in plantations for its exudate, of which mainly rubber is made. Hevea is classified by Webster (1994) and Radcliffe-Smith (2001) in the subfamily Crotonoideae, tribe Micrandreae, subtribe Heveinae. The genus is easily recognised, because it is one of the very few genera in the Euphorbiaceae with a trifoliolate leaf and white latex, leaflets papery, flower actinomophic, calyx 5- or 6-lobed, stamens 5-10 united in 1 or 2 layers, ovary 3-5-locular, the fruits large capsules and the seeds are big for Euphorbiaceae and show a kind of camouflage design with areas of different shades of yellow to brown.

Because we are dealing with one widely cultivated species and two occasional species in botanical gardens, the nomenclature is kept simple, only the accepted name is presented and synonyms based on the same type. Most species concepts in Hevea are complicated and many synonyms and infraspecific taxa were described.

\section{Hevea Aubl.}

Hevea Aubl. (1775) 871, t. 335; Müll.Arg. (1866) 716; Pax (1910) 117; Ducke (1935) 217; Corner (1940) 256; R.E. Schult. (1970a) 197; (1970b) 229; (1977) 243; (1987) 125; G.L. Webster (1994) 99; Radcl.-Sm. (2001) 271. - Type: Hevea guianensis Aubl. 
Siphonia Rich. in Schreb. (1791) 656, nom. superfl. - Lectotype (Webster, 1994): Siphonia elastica Pers. [= Hevea guianensis Aubl.].

Caoutchoua J.F. Gmel. (1791) 677, nom. superfl. - Type: Caoutchoua elastica J.F. Gmel. [= Hevea guianensis Aubl.].

Micrandra R.Br. in Benn. \& R. Br. (non Benth.) (1844) 237, nom. rejic. - Type: Micrandra ternata R.Br. [= Hevea guianensis Aubl.].

Siphonanthus Schreb. ex Baill. (1858) 324. - Type: Siphonanthus elastica Schreb. ex Baill. [= Hevea guianensis Aubl.].

Monoecious trees. Latex white. Indumentum of simple hairs, glabrous except for inflorescence and sometimes the lower leaf surface. Stipules very early caducous. Leaves alternate, trifoliolate, long petiolate; leaflets symmetric, papery, basally attached, with 2 or 3 glands at the base, margin entire to wavy; venation pinnate, nerves looped and closed near margin, veins scalariform, veinlets reticulate. Inflorescences axillary to pseudoterminal panicles, single per axil, often in groups; bracts small, triangular; staminate flowers in cymules, pistillate flowers single at end of branches. Flowers actinomorphic; calyx 5-lobed, valvate, lobes ovate, apically pointed and often bent; petals absent, disc glands absent or 5, free or united, opposite sepalous. Staminate flowers: stamens 4-10, filaments united, in 1 or 2 layers above each other, anthers free, 2-locular, sessile; pistillode present. Pistillate flowers: calyx basally thickened, ovary 3- or 4-locular, apically beaked; ovules 1 per locule; stigmas sessile with horizontal short lobes. Fruits large capsules, trilobed, obtusely or acutely trigonous, septicidally dehiscent into three bivalved cocci (partly dehisced loculicidally), endocarp woody, column persistent. Seeds ellipsoid, ecarunculate, testa crustaceous, smooth, marbled; endosperm scanty or absent; cotyledons thick.

Distribution - Ten species in Amazonian South America, one of great economic importance and found cultivated throughout the tropics. Two other species occasionally present in Malesian botanical gardens.

\section{KEY TO THE MALESIAN SPECIES}

1a. Leaf blade hairy to glabrescent underneath. Stamens 4-6 in one whorl and disc glands absent or stamens 10 in 2 whorls and disc glands present . . . . . 2

b. Leaf blade glabrous underneath. Stamens 10 in 2 whorls and disc glands absent

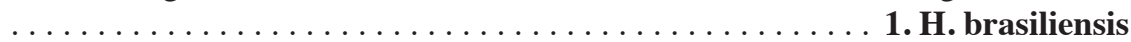

2a. Stamens (4 or) 5 (or 6) in a single whorl. Disc glands absent . . 2. H. guianensis

b. Stamens 10 in 2 whorls. Disc glands present . . . . . . . 3. H. pauciflora

\section{Hevea brasiliensis (Willd. ex A. Juss.) Müll.Arg. - Fig. 3}

Hevea brasiliensis (Willd. ex A. Juss.) Müll.Arg. (1865) 204; (1866) 718; Pax (1910) 121; Ducke ( 1935) 226; Corner (1940) 256; R.E. Schult. (1950) 79; (1953) 26; (1970a) 197; (1970b) 239; (1977) 243; (1987) 125; Radcl.-Sm. (1987) 183, f. 36. - Siphonia brasiliensis Willd. ex A. Juss. (1824) pl. 12: 38 (see note). - Lectotype (Schultes, 1950): F. G. Sieber via Hoffmansegg in Herb. Willdenow sheet 17936 (holo B-WILLD; iso in G, P n.v.; IDC microfiche 7440-29, negative 1028/2), Brazil, Pará Prov., Rio Amazonas.

For other synonyms see the various publications of R.E. Schultes (esp. 1950, 1970a, b, 1987).

Tree, up to $30 \mathrm{~m}$ high. Stipules not seen. Leaves: petiole 3-23.2 cm long; petiolules $5-10 \mathrm{~mm}$ long; leaflets elliptic or obovate, $5-23.5$ by $2.2-8.8 \mathrm{~cm}$, length/width ratio 


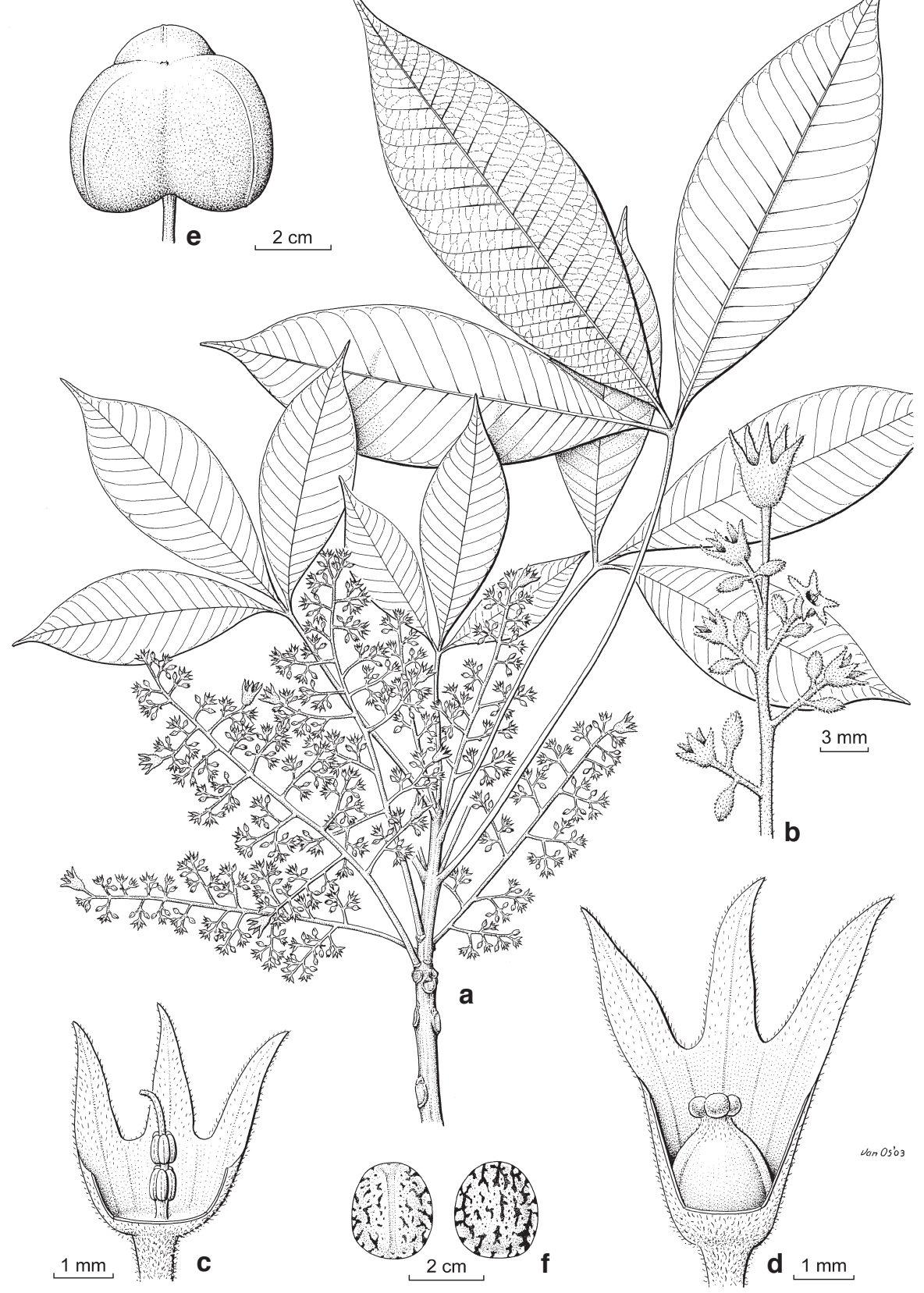

Fig. 3. Hevea brasiliensis (Willd. ex A. Juss.) Müll.Arg. a. Habit; b. part of inflorescence with staminate flowers (small) and a terminal pistillate flower (large); c. staminate flower with part of calyx removed; d. pistillate flower with part of calyx removed; e. fruit; $\mathrm{f}$. seed in ventral and dorsal view (a-d: Herb. C. d'Alleizette s.n., June 1913, barcode L 0034117; e: KEP FRI (Kochummen) 30995; f: unlabelled material economic botany collection; all L). 
2.3-2.7, reclinate, base attenuate, apex acuminate to cuspidate, both surfaces glabrous, venation distinct on both sides, nerves 14-27 till apex, flat above, raised underneath. Inflorescences up to $31 \mathrm{~cm}$ long, glabrous to hairy, branches up to $6.2 \mathrm{~cm}$ long, peduncle $1-4.6 \mathrm{~cm}$ long; bracts $5-8$ by $2-4 \mathrm{~mm}$. Staminate flowers $4.5-5 \mathrm{~mm}$ diam., yellowish, sweet scented; pedicel $0.6-3.2 \mathrm{~mm}$ long; calyx $4.5-6.2 \mathrm{~mm}$ long, lobes $2-4.5$ by $0.5-1.5 \mathrm{~mm}$; androphore $2.2-2.8 \mathrm{~mm}$ long, stamens 10 , united in two layers, anthers $0.5-0.8$ by $0.2-0.3 \mathrm{~mm}$; disc glands absent; pistillode $0.8-1 \mathrm{~mm}$ long. Pistillate flowers $5-5.6 \mathrm{~mm}$ diam.; calyx $5-7.4 \mathrm{~mm}$ high, lobes $3-4.5$ by $1-1.8 \mathrm{~mm}$; disc glands absent; ovary $2-2.4$ by $1.8-2.1 \mathrm{~mm}$, hairs on ovary; stigmas c. $0.2 \mathrm{~mm}$ long. Fruits $4-5$ by $3.2-4.8 \mathrm{~cm}$, wall $3-4 \mathrm{~mm}$ thick, unripe green, brown when ripe; pedicel $0.6-2.5 \mathrm{~cm}$ long; column $25-32 \mathrm{~mm}$ long. Seeds $2.3-2.6$ by $1.9-2.1$ by $1.4-1.6 \mathrm{~cm}$.

Distribution - Only known from cultivation, originally only from Amazonian South America, presently cultivated worldwide in tropical regions.

Habitat \& Ecology - Reported wild and common in evergreen forest, probably escaped from abandoned plantations; once reported from limestone. Altitude: sea level up to $200 \mathrm{~m}$. Flowering and fruiting throughout the year.

Vernacular names - General names: Para rubber, rubber (English). Viet Nam: Cao su. Malay Peninsula: Gehta para, ka-toh. Sumatra: Para (Jami). Java: Karet kipia, Cautchuc. Borneo (Sabah): Fatok para ( Bidayuh).

Uses - Of high economic value. The bark is tapped for its latex by making shallow, $\mathrm{V}$-shaped cuts over $1 / 3$ of the circumference, working from c. $2 \mathrm{~m}$ high toward the root, moving to the next third once a row is finished. The latex comprises elastic strings of polymers of cis-polyisoprene, which, when still unvulcanised, are easily detached from each other and they are therefore used in chewing gum [NB: Hevea is one of the few Euphorbiaceae with a non-poisonous latex]. Vulcanised (mixed with sulphur and baked) the strings become solidly attached to each other and have many applications as rubber. Natural rubber is more elastic and durable than artificial rubbers. Its main use is undoubtedly in tires (next to condoms due to the HIV virus). The tires are presently more and more re-used as furniture, shoes, and waste baskets in SE Asia and in a new kind of tarmac in Europe.

When the latex production of the fast growing trees decreases they are cut and the wood, though not durable and strong, is more and more used in Thailand for the production of beautiful, light coloured furniture and wooden toys for children.

Note - The interpretation of Hevea brasiliensis is difficult, because it is only known from cultivation and, consequently, many synonyms, varieties, cultivars, etc. have been described in the course of time. This is not the only difficulty, also the correct interpretation of the concept of the species and the first publication of the name are troublesome. De Jussieu (1824) published the name Siphonia brasiliensis first, but this is apparently a nomen nudum. Luckily the ICBN allows detailed drawings to be valid descriptions and De Jussieu's plate is very detailed. This is fortunate because one year later Kunth (1825) also used the name Siphonia brasiliensis for two distinct plants, one from Venezuela (Orinoco) and the other from Brazil (lower Amazon). The latter is the cultivated species. De Jussieu used a specimen from the Willdenow herbarium. There are three sheets named Siphonia brasiliensis, but only one is identified as Hevea brasiliensis by Schultes, the others bear the identification H. pauciflora. This means that only one sheet should be taken as lectotype. 


\section{Hevea guianensis Aubl.}

Hevea guianensis Aubl.(1775) 871,t. 335; Müll.Arg. (1865) 204; (1866) 719; Pax (1910) 127,f. 44; Ducke (1935) 223; R.E. Schult. (1970a) 222; (1970b) 235; (1977) 243 - - Caoutchoua guianensis (Aubl.) O.F. Cook (1941) 58 - Type: Aublet s.n.(BM), Guianas, Cayenne, 1775.

This species is rather variable and widespread, many synonyms exist (see Pax, 1910; Schultes, 1970a, b).

Tree, up to $40 \mathrm{~m}$; foliage dense and very dark. Stipules not seen. Leaves: petiole 4.5-9 (-28) cm long; petiolules 6-10 mm long; leaflets elliptic to obovate, 5.4-15.2(-33.8) by $2.7-5.3(-10.2) \mathrm{cm}$, length/width ratio $2-3.3$, erect, base obtuse to cuneate, apex rounded to acuminate at apex, upper surface glabrous, lower surface hairy, venation flat above, raised underneath, nerves 9-25 till apex. Inflorescences up to $20.2 \mathrm{~cm}$ long, pubescent, branches up to $7.3 \mathrm{~cm}$ long; bracts c. 1.2 by $0.3 \mathrm{~mm}$. Staminate flowers 4-4.5 mm diam; pedicel 2-8 mm long; calyx 4-4.7 mm high, lobes $1.5-2.2$ by $0.8-1.5 \mathrm{~mm}$, stamens ( 4 or) 5 (or 6 ) forming a single regular verticil, but some specimens having one anther inserted a little below the others, anthers $0.5-0.7$ by $0.2-0.3$ $\mathrm{mm}$; disc glands absent; pistillode 5-6.5 mm long. Pistillate flowers 4.6-5 mm diam.; calyx $4.7-5.7 \mathrm{~mm}$ high, lobes $1.7-2$ by $1-1.4 \mathrm{~mm}$; disc glands absent; ovary $1.8-2.8$ by $1.6-2.2 \mathrm{~mm}$, densely hairy; stigma $0.5-0.8 \mathrm{~mm}$ long. Fruits globose, c. 4.8 by 4.1 $\mathrm{cm}$, wall $3.5-3.8 \mathrm{~mm}$ thick; pedicel 1-2.5 cm long; column $2.5-2.7 \mathrm{~cm}$ long. Seeds c. 2.4 by 1.4 by $1 \mathrm{~cm}$.

Distribution - Tropical South America, from the Guianas to Amazonia. Once cultivated in the botanical garden of Bogor (former called Buitenzorg) in Indonesia.

Habitat \& Ecology - Flowering: August to October; fruiting: November to December.

\section{Hevea pauciflora (Spruce ex Benth.) Müll.Arg.}

Hevea pauciflora (Spruce ex Benth.) Müll.Arg. (1865) 203; (1866) 717; Pax (1910) 126; Ducke (1935) 224; R.E. Schult. (1952) 255; (1970a) 223; (1970b) 229; (1977) 243. - Siphonia pauciflora Spruce ex Benth. (1854) 370. - Type: Spruce 2691 (K n.v.), Brazil, Rio Uaupés.

For further synonyms see the various publications of Schultes (esp. 1952, 1970a, b).

Tree, up to $30 \mathrm{~m}$ high. Bark dark brown, c. $1 \mathrm{~mm}$ thick; inner bark light brown, c. 1.5 cm thick; wood white. Stipules not seen. Leaves: petiole 5-21.4 cm long; petiolules $3-10 \mathrm{~mm}$ long; leaflets obovate, $6.7-24.5$ by $2.9-10.2 \mathrm{~cm}$, length/width ratio $2.3-2.4$, reclined to semi-erect, base attenuate to cuneate, apex acuminate to cuspidate, upper surface glabrous, lower surface subglabrous, venation pinnate, flat above, raised beneath, nerves 10-23 till apex. Inflorescences up to $37.4 \mathrm{~cm}$ long, hairy, branches up to $11.5 \mathrm{~cm}$ long; bracts very small. Staminate flowers 4-5.2 mm diam., yellowish, sweet scented; pedicel 3-24 mm long; calyx 4.7-5.4 mm long, lobes $2.8-3.4$ by $1.2-1.5$ $\mathrm{mm}$; androphore 2.5-2.8 mm long, stamens 10, united in two layers, anthers, 0.7-0.8 by c. $0.2 \mathrm{~mm}$; disc glands present; pistillode 5.6-7.9 mm long. Pistillate flowers $5-5.4$ $\mathrm{mm}$ diam.; calyx $6.5-7.2 \mathrm{~mm}$ high, lobes $4.1-4.5$ by $1-1.5 \mathrm{~mm}$; disc glands $1-1.2 \mathrm{~mm}$ high; ovary $2.2-2.5$ by $2-2.2 \mathrm{~mm}$, hairy; stigmas $0.2-0.3 \mathrm{~mm}$ long. Fruits $4-4.5$ by $3.8-4.1 \mathrm{~cm}$ high, wall $3.5-4 \mathrm{~mm}$ thick; pedicel $0.8-2 \mathrm{~cm}$ long; column $2.5-2.8 \mathrm{~cm}$ long. Seeds $2.2-2.3$ by $1.7-1.9$ by $1.5-1.6 \mathrm{~cm}$. 
Distribution - South America: North Amazonia and British Guyana. Once cultivated in the botanical garden of Bogor (former called Buitenzorg) in Indonesia.

Habitat \& Ecology - Flowering: July to November; fruiting: October to January.

\section{EXCLUDED SPECIES}

\section{Elateriospermum tokbrai Blume (1825) 621. = Mallotus tokbrai (Blume) Müll.Arg. $=$ Blumeodendron tokbrai (Blume) Kurz.}

\section{ACKNOWLEDGEMENTS}

We like to thank ARCBC (ASEAN Regional Center for Biodiversity Conservation) for support funds, Petra Hoffmann for sending images of some of the Hevea types; Freek Kiehl for extracting photocopies from various institutes, Frits Adema for critically reviewing the manuscript, the referee for the useful comments (not too anonymous regarding his main type of comments), and Jan van Os for his very beautiful drawings.

\section{REFERENCES}

Airy Shaw, H.K. 1960. The taxonomic position of the genus Deutzianthus Gagnep. Kew Bull. 14: 363.

Airy Shaw, H.K. 1963a. Rediscovery of Annesijoa Pax \& K. Hoffm. in New Guinea. Kew Bull. 16: 345 .

Airy Shaw, H.K. 1963b. Elateriospermum Blume in Siam. Kew Bull. 16: 371, 372.

Airy Shaw, H.K. 1967. Tapoides villamilii (Merr). Hooker's Icon. Pl. 37: t. 3632, p.3.

Airy Shaw, H.K. 1972. The Euphorbiaceae of Siam. Kew Bull. 26: 258.

Airy Shaw, H.K. 1974. Annesijoa novoguineensis Pax \& Hoffm. Hooker's Icon. Pl. 38: t. 3713.

Airy Shaw, H.K. 1975. The Euphorbiaceae of Borneo. Kew Bull., Addit. Ser. 4: 108, 109.

Airy Shaw, H.K. 1980. The Euphorbiaceae of New Guinea. Kew Bull., Addit. Ser. 8: 27, 28, 115.

Airy Shaw, H.K. 1981. The Euphorbiaceae of Sumatra. Kew Bull. 36: 292, 293.

Aublet, J.B.C.F. 1775. Histoire des plantes de la Guiane Française 2: 871-873, t. 335. Didot jeune, Paris.

Backer, C.A. \& R.C. Bakhuizen van den Brink Jr. 1964. Flora of Java 1: 496, 497. Noordhoff, Groningen.

Baillon, M.H. 1858. Étude générale du groupe des Euphorbiacées: 324-327. Masson, Paris.

Bennett, J.J. \& R. Brown. 1844. Plantae Javanicae Rariores: 237. Allen \& Socios, London.

Bentham, G. 1854. On the North Brazilian Euphorbiaceae in the collection of Mr. Spruce. J. Bot. (Hooker) 6: 321-377.

Bentham, G. 1879. Elateriospermum tapos Blume. Hooker's Icon. Pl. 13: 73, 74, pl. 1294.

Blume, C.L. 1825. Bijdragen tot de Flora van Nederlandsch Indië: 620, 621. Lands Drukkerij, Batavia.

Boerlage, J.G. 1900. Handleiding tot de kennis der Flora van Nederlandsch Indië 3, 1: 226, 227. Brill, Leiden.

Burkill, I.H. 1935. A dictionary of the economic products of the Malay Peninsula 1: 905, 906. Governments of the Straits Settlements, London.

Cook, O.F. 1941. Naming the cultivated rubber tree Siphonia ridleyana. J. Wash. Acad. Sci. 31: $46-65$.

Corner, E.J.H. 1940. Wayside trees of Malaya 1: 249, 256. The Government Printing Office, Singapore.

De Jussieu, A. 1824. De Euphorbiacearum generibus: pl. 12: 38A: 1-4. Didot Junioris, Parisiis.

Ducke, A. 1935. Revision of the genus Hevea Aubl., mainly the Brazilian species. Arq. Inst. Biol. Veg. 2: 217-240.

Gmelin, J.F. 1791. Systema Naturae, ed. 13, 2: 677, 1007. Georg Manuel Boor, Lipsiae. 
Heyne, K. 1927. De nuttige planten van Nederlandsch Indië, ed. 2, 2: 942, 943. Departement van Landbouw, Nijverheid \& Handel in Nederlandsch-Indië, Batavia.

Hooker, J.D. 1887. Flora of British India 5: 381, 382. Reeve \& Co., London.

Kunth, C.S. 1825. In: F.W.H.A von Humboldt, A.J.A. Bonpland \& C.S. Kunth, Nova Genera et Species Plantarum 7: 170, 171. Gide Filium, Luteciae Parisiorum.

Linnaeus, C. 1781. Supplementum Plantarum Systematis Vegetabilum: 422. Brunsvigae.

Medway, L. 1972. Phenology of a tropical rain forest in Malaya. Biol. J. Linn. Soc. 4, 131.

Meijer, W. 1964. Notes on hill Dipterocarp forests along Gunong Lumaku's East side and the Crocker Range near Tenom. Bot. News Bull. Forest Dept., Sabah 2: 17.

Meijer, W. 1967. Family Euphorbiaceae. Bot. News Bull. Forest Dept., Sabah 7: 25.

Merrill, E.D. 1921. A bibliographic enumeration of Bornean plants. J. Straits Branch Roy. Asiat. Soc., Special number: 344.

Müller Argoviensis, J. 1865. Euphorbiaceae. Linnaea 34: 203, 204.

Müller Argoviensis, J. 1866. Euphorbiaceae. In: A. de Candolle (ed.), Prodromus Systematis Naturalis Regni Vegetabilis 15, 2: 716-719, 1130, 1131. Masson \& Filii, Parisiis.

Pax, F. 1910. Euphorbiaceae-Jatropheae. In: A. Engler (ed.), Das Pflanzenreich IV.147.i: 17, 18, 117-128, f. 44. Engelmann, Leipzig.

Pax, F. \& K. Hoffmann. 1919. Euphorbiaceae - Additamentum VL. In: A. Engler (ed.), Das Pflanzenreich IV.147.xiv: 9. Engelmann, Leipzig.

Pax, F. \& K. Hoffmann. 1931. Euphorbiaceae. In: A. Engler \& H. Harms (eds), Die natürlichen Pflanzenfamilien, ed. 2, 19c: 101. Engelmann, Leipzig.

Radcliffe-Smith, A. 1987. Euphorbiaceae (Part 1). In: R.M. Polhill (ed.), Flora of Tropical East Africa: 183-185, f. 36. Balkema, Rotterdam, Boston.

Radcliffe-Smith, A. 2001. Genera Euphorbiacearum: 271, 286, 293. Royal Botanic Gardens, Kew.

Ridley, H.N. 1924. The Flora of the Malay Peninsula 3: 252, 253. Reeve \& Co., Ashford, Kent.

Schultes, R.E. 1950. Studies in the genus Hevea III, on the use of the name Hevea brasiliensis. Bot. Mus. Leafl. 14: 79-86.

Schultes, R.E. 1952. Studies in the genus Hevea VI. Notes, chiefly nomenclatural, on the Hevea pauciflora complex. Bot. Mus. Leafl. 15: 255-272.

Schultes, R.E. 1953. Studies in the genus Hevea VII. Bot. Mus. Leafl. 16: 21-44.

Schultes, R.E. 1970a. The history of taxonomic studies in Hevea. Bot. Rev. 36: 197-276.

Schultes, R.E. 1970b. The history of taxonomic studies in Hevea. Regnum Veg. 71: 229-293.

Schultes, R.E. 1977. A new intergenetic classification of Hevea. Bot. Mus. Leafl. 25: 243-248.

Schultes, R.E. 1987. Studies in the genus Hevea VIII. Notes on the infraspecific variants of Hevea brasiliensis (Euphorbiaceae). Econ. Bot. 41: 125-147.

Smith, J.J. 1910. Addimenta ad cognitionem Florae arboreae javanicae auctoribus S.H. Koorders et Th. Valeton. Meded. Dept. Landb. Ned.-Indië 10: 571-575.

Smitinand, T. 2001. Thai plant names, revised edition: 215. The Forest Herbarium, Bangkok.

Von Schreber, J.C.D. 1791. Genera Plantarum, ed. 8, 2: 656. Varrentrappii \& Wenneri, Francoforti ad Moenum.

Webster, G.L. 1994. Synopsis of the genera and suprageneric taxa of Euphorbiaceae. Ann. Missouri Bot. Gard. 81: 99, 104.

Whitmore, T.C. 1973. Tree Flora of Malaya 2: 91, 92, f. 6. Longman, London.

\section{IDENTIFICATION LIST}

The numbers after the collector numbers refer to the following species:

$$
\begin{array}{ll}
1=\text { Annesijoa novoguineensis } & 3=\text { Hevea brasiliensis } \\
2=\text { Elateriospermum tapos } & 4=\text { Hevea guianensis } \\
& 5=\text { Hevea pauciflora }
\end{array}
$$

Ambriansyah \& Arifin W-330: 3 - ANU series 27826: 2 - Arifin \& Ambriansyah B-812: 2; B-1001: 2-Arifin et al. B-916: 2 - Avé 79: 2. 
Baker 54: 3 - Bakhuizen van den Brink Sr. 74: 3; 6371: 2; 7663: 2 - Balakrishnan \& Bhargava 3472: 3 - bb series 2277: 2; 6353: 2; 6416: 2; 7025: 2; 7176: 2; 15231: 2; 15235: 2; 15552: 3; 16379: $2 ; 16741: 2 ; 17756: 2 ; 17955: 2 ; 18285: 2 ; 18483: 2 ; 23706: 2 ; 24025: 2 ; 29264: 2 ; 29531$ : 2; 32144: 2; 33095: 2 - Blume 2127: 2 - Bogor Botanical Garden VIII.H.11: 5; VIII.H.17: 5; IX.A.13: 5; IX.A.127a: 3; IX.A.129: 2; IX.A.131: 3; IX.A.131a: 3 - Boschproefstation 82E.1P.751: 2; 82E.1P.936: 2; 82E.3P.807: 2; T.B.624: 2; T-792: 2; T-794: 2 - Brass 7430: 1; 32333: 1; 32407: 1 - Brooke 10593: 3 - BRUN series 44: 2; 1570: 2; 3301: 2; 16863: 2 - Burchell 9826: 3 - Burley et al. 808: 2; 1600: 2 - BW series 5309: 1; 13043: 1; 13047: 1; 13051: 1 ; 13446: 1; 13778: 1 .

Church, Mahyar \& Afriastini 1403: 2 - Coode 6820: 2.

De Vogel 719: 2; 813: 2 - De Wilde \& De Wilde-Duyfjes 14560: 2; 15466: 2 - Dickason 6958: 3 — Dransfield 7298: 2 - Ducke RB 20599: 4; RB 21962: 5 - Dumas 1642: 2.

Elmer 20022: 3; 20983: 3; 21470: 2 - Endert 82E.1P.751: 2.

Forbes 2767: 2 - Frodin \& Ismawi 2022: 2.

Grashoff 281: 2 .

Hart 6085: 3 - Hoogland \& Craven 10193: 1 - Hou 834: 3 - Huber 9402: 3.

Kadim \& Noor 400: 2 - Kasim \& Rahim 618: 3 - KEP series 79032: 2; 80171: 2; 80217: 2; 94279 : 2; 99468: 2; 104396: 2; 110392: 2 - KEP FRI series 91: 2; 1307: 2; 4799: 2; 7543: 2; 7723: 2; 11301: $2 ; 11597: 2 ; 13015: 2 ; 13891: 2 ; 13944: 2 ; 14054: 2 ; 14578: 2 ; 15321: 2 ; 15861: 2 ; 18192$ : 2; 20990: 2; 21961: 2; 21962: 2; 23011: 2; 29005: 3; 30995: 3 - Kerr 14392: 3 - Keßler et al. B-138: 2; B-653: 2 - King's collector 7069: 2 - KL series 3191: 2; 3309: 2 - Kochummen 30995: 1 - Koerniasih 27: 5 - Koninklijk Instituut voor de Tropen 3510: 3 - Koop 26: 2 - Kostermans 12549: 2; 13611: 2 - Kramadibrata 206: 2.

LAE series 51712: 1; 56312: 1; 76178: 1 - Lambach 1235: 2 - Larsen et al. 45624: 2.

Maingay KD 1440: 2 - Murata, Fukuoka \& Phengklai T-17427: 3.

Nangkat 219: 2 - NGF series 11576: 3; 26183: 1; 31831: 1; 33346: 1; 33424: 1; 48231: 1; 48435: 1. Ogata 10001a: 3; 10042a: 2; 10458: 2; 19316: 3 - Ogata et al. Og-B 456: 2.

Peters 1056: 2 - Phusomsaeng 379: 3 - Polak 960: 1 - Posthumus 676: 3 - PPI series 1703: 3; 6310: 3 - Prance 30709: 2 - Pullen 7319: 1.

Rabil 254: 2 - Rahmat Si Boeea (= Rahmat Si Toroes) 5503: 3; 9321: 2 - Rastini 76: 4; 126: 5; 127: 5 - Reksodihardjo 376: 1 .

S series 10301: 2; 19116: 2; 21470: 2; 21707: 2; 22203: 2; 25251: 2; 26902: 2; 29669: 2; 33460: 2; 33479: 3 ; 34240: 2 ; 34251: 2 ; 35872: 2; 36000: 2 ; 40675: 2; 42482: 2 ; 42526: 2 ; 42947: 2 ; 49892: 2; 60200: 2 - SAN series 17436: 2; 30198: 2; 35072: 2; 43240: 2; 63152: 2; 65294: 2; 67583: 2; 72009: 2; 72483: 2; 78081: 2 ; 78401: 2 ; 85838: 2; 91367: 2; 94953: 2; 96286: 2 ; 109800: 2 - J.V. Santos 4228: 3 - Schiffner 64: 3 - Schultes 6043: 4; 6044: 3; 8050: 3; 8115: 5; 8226: 4; 8250: - SF series 35518: 3; 40079: 2 - Sidiyasa 1229: 2; PBU 319: 2 - A.C. Smith 9440: 3 - Soepadmo \& Suhaimi 193: 2 - Spence 136: 3 - Stahel 155: 4 - Suzuki K 9692: 2.

Takeuchi 6269: 1 .

Ule 5348: 5; 5349: 4; 5353: 3; 5893: 3; 5895: 4; 5897: 4; 6260: 5; 9550: 3.

Van Balgooy 2260: 2 - Van Harreveld 4436: 3.

Waas 709: 3 - Hubert Winkler 2409: 2 - Wiriadinata 611: 2; 1164: 2; 3506: 2 - Woerjantoro 85: 5 .

Yates 2634: 3.

Zainudin et al 5161: 2 - Zenker 3917: 3 . 